Gerontology 1986;32(Suppl. 1):1-2

\title{
Contents, Supplement 1, 1986
}

I. Present Status on Ageing

Epidemiology of Aging and Its Effects on the Nervous System

Plum, F $\quad 3$

Positron Emission Tomography in Normal Aging and Alzheimer's Disease

Rapoport, S.I 6

Depression in the Fifties

Hamilton, M 14

Quantitative Detection of Cerebral Arteriosclerosis by Means of the Doppler Ultrasonic

Technique

Miyazaki, M 17

Experimental Studies of Ageing: Behavioural and Physiological Correlates

Soumireu-Mourat, B 24

Psychometric Scales for Dementia

Hamilton, $\mathrm{M} 30$

II. Therapeutics in Ageing and New Trends in Ageing Studies

The Experimental Basis of Therapeutics in Ageing

Rapin, J.R 33

The Predictive Value of Animal Experimentation for Clinical Geropsychopharmacology

Giurgea, G 37

Brain Water and Aging

Cohadon, F.; Desbordes, P 46

Demonstration of Peri vascular Peptides and Changes in Concentration with Age in Man

Edvinsson, L.; Ekman, R.; Ottosson, A 50

2 Contents

Age and Learning: Experimental and Clinical Aspects

Le Poncin Lafitte, M.; Rapin, J.R 53

Psychometric Tests in Ageing

Rotrou, J.M. de; Le Poncin Lafitte, M.; Lafitte, J.C 60

III. Dementia

Dementia - A Semantic Definition

Loo, H.; Plas, J

64

The Pathophysiology of Dementia

Plum, F

67

Heredity and Dementia

Constantinidis, J 73

Classification as a Function of the Degree of Dementia

Hoyer, $\mathrm{S}$

80

Regional Cerebral Blood Flow and Oxygen Metabolism in Dementia due to Vascular Disease

Gibbs, J.M.; Frackowiak, R.S.J.; Legg, N.J 84 
Clinical and Neuropsychological Rating Scales for Differential Diagnosis of Dementias Baldy-Moulinier, M.; Valmier, J.; Touchon, J.; Rondouin, G.; Brun, M

Alzheimer's Disease

Gottfries, C.G 98

Ageing and Parkinson's Disease

Rondot, P.; Bianco, C; Recondo, J. de

Abstract

$\mathrm{S}$

Le vieillissement: Etat actuel des connaissances

Ageing Research: State of the Art 106

A. Author Index 126

Subject Index 128 